\title{
Cytoplasmic expression of CD133 is an important risk factor for overall survival in hepatocellular carcinoma
}

\author{
AYAMI SASAKI ${ }^{1}$, TOSHIYA KAMIYAMA $^{1}$, HIDEKI YOKOO $^{1}$, KAZUAKI NAKANISHI $^{1}$, \\ KANAKO KUBOTA ${ }^{2}$, HIRONORI HAGA ${ }^{2}$, MICHIAKI MATSUSHITA ${ }^{3}$, \\ MICHITAKA OZAKI ${ }^{4}$, YOSHIHIRO MATSUNO ${ }^{2}$ and SATORU TODO ${ }^{1}$ \\ ${ }^{1}$ Department of General Surgery, Hokkaido University Graduate School of Medicine; ${ }^{2}$ Department of Surgical Pathology, \\ Hokkaido University Hospital; Departments of ${ }^{3}$ Health and Science and ${ }^{4}$ Molecular Surgery, \\ Hokkaido University School of Medicine, Sapporo, Japan
}

Received January 8, 2010; Accepted March 19, 2010

DOI: $10.3892 /$ or_00000890

\begin{abstract}
CD133 antigen has been used to identify cancer stem cells in several solid tumor types, including hepatocellular carcinomas (HCCs). The aim of this study was to investigate whether the expression and subcellular localization of CD133 correlated with the clinicopathological factors, recurrence, and survival in HCC patients. Tissue specimens from $136 \mathrm{HCC}$ patients who underwent curative primary hepatectomy between 2000 and 2005 were collected and immunohistochemically analyzed for CD133 expression. Positive immunohistochemical results and subcellular localization of CD133 were determined, and the correlation between CD133 expression and clinicopathological factors of HCC patients were evaluated. CD133-positive tumor cells were observed in $30(22.1 \%)$ cases. Cytoplasmic and membranous expressions were observed in $22(16.2 \%)$ and 20 (14.7\%) of the CD133-positive cases, respectively. Positive cytoplasmic expression of CD133 was found to be associated with the overall survival of HCC patients, especially in stage III and IVA HCC patients $(\mathrm{p}=0.0092)$. Univariate analysis revealed that pre-operative serum albumin, $\alpha$-fetoprotein (AFP) levels, tumor size, portal venous invasion, and cytoplasmic CD133 expression were important risk factors in HCC. Multivariate analysis revealed that among the factors related to tumor aggressiveness, cytoplasmic expression of CD133 showed the most significant association with overall survival, although the difference was not statistically significant $(\mathrm{P}=0.0681)$. Cytoplasmic expression of $\mathrm{CD} 133$ was a significant risk factor for the overall survival of $\mathrm{HCC}$
\end{abstract}

Correspondence to: Dr Ayami Sasaki, Department of General Surgery, Hokkaido University Graduate School of Medicine, North 15, West 7, Kita-ku, Sapporo 060-8638, Hokkaido, Japan

E-mail: ayami-s@med.hokudai.ac.jp

Key words: CD133, cytoplasmic expression, hepatocellular carcinoma patients. Patients with stage III and IVA HCC showing positive cytoplasmic expression of CD133 are more likely to have a worse prognosis.

\section{Introduction}

Hepatocellular carcinoma (HCC) accounts for $5.7 \%$ of all cancers, excluding skin tumors, worldwide (1). Because of the very poor prognosis, the number of new HCC cases and the number of deaths from $\mathrm{HCC}$ has remained almost the same despite of the recent progress in treatment strategies. Most of the HCC patients who undergo hepatic resection or additional locoregional therapy develop local and remote recurrence $(2,3)$. Ikeda et al (4) reported that the hepatocellular carcinogenesis rates for the patients with cirrhosis caused by hepatitis B or hepatitis C virus were $49 \%$ at the tenth year, and for those who underwent curative surgical or locoregional therapy, the rate of recurrence was $75 \%$ at the fifth year and $89 \%$ at the tenth year. The molecular mechanisms underlying the development and progression of HCCs remain unclear.

Recently, the mechanisms of normal stem cells has been applied for cancer cells. Cancer stem cells have the ability to self-renew and differentiate, thereby sustaining tumor growth (5). To date, the existence of cancer stem cells has been confirmed in leukemia (6), as well as in several solid tumors, including brain tumors (7) and breast (8), pancreatic (9), lung (10), and colorectal cancers $(11,12)$. Cancer stem cells might be able to withstand radiation and chemotherapy, due to the preferential expression of resistance molecules or activation of specific signaling pathways (13). CD133 has been used to identify cancer stem cells in various tumors. CD133 antigen is a 5-transmembrane glycoprotein and was originally identified as a cell surface antigen present on $\mathrm{CD} 34^{+}$hematopoietic stem cells (14). It has been shown that CD133positive cells isolated from HCC cell lines have the ability to efficiently form tumors in mice $(15,16)$, supporting the cancer stem cell hypothesis.

However, the clinicopathological significance of CD133 in HCCs remains controversial $(17,18)$. Therefore, we designed this study to investigate the potential clinical role 

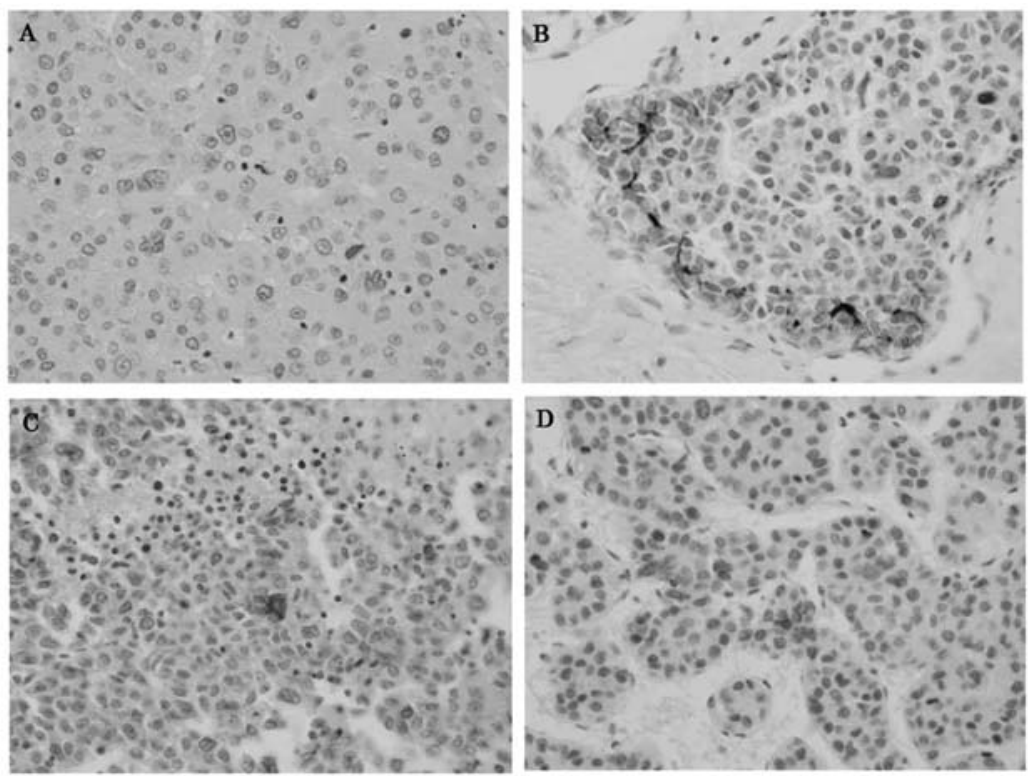

Figure 1. CD133 immunoreactivity in hepatocellular carcinoma. (A) Negative immunostaining for CD133 in tumor cells. (B) Positive membranous immunostaining for CD133 in tumor cells. (C) Diffuse cytoplasmic immunostaining for CD133 in tumor cells. (D) Perinuclear dot-like immunostaining for CD133 in tumor cells. Original magnification, $\mathrm{x} 400$.

of the immunohistochemically expressed CD133 in a large series of HCC patients.

\section{Materials and methods}

Patients and tissue specimens. Tissue specimens were collected from 136 consecutive HCC patients who underwent primary curative hepatectomy at the First Department of Surgery, Hokkaido University Hospital, during the period between 2000 and 2005. Of the 136 patients, 112 were male, 71 were $>60$ years old (mean age, 61, range, 35-78), 54 $(39.7 \%)$ were positive for the hepatitis B virus surface antigen (HBs-Ag) alone, $48(35.3 \%)$ were positive for the hepatitis $\mathrm{C}$ virus antibody (HCV-Ab) alone, 28 (20.6\%) were negative for both HBs-Ag and HCV-Ab, and 6 (4.4\%) were positive for both $\mathrm{HBs}-\mathrm{Ag}$ and $\mathrm{HCV}-\mathrm{Ab}$. As per the macroscopic typing of HCC, which was advocated by the Liver Cancer Study Group in Japan (19), the patients could be classified into the single nodular type, single nodular with extranodular growth type, confluent multinodular type, and infiltrative type. On the basis of these types, we subclassified the patients into 2 groups: nodular and extensive. The single nodular type was considered as the nodular group (80 cases), and the remaining were included in the extensive group (56 cases). The dimensions of each specimen were measured to determine the tumor size. Tumors were staged and graded according to the Liver Cancer Study Group of Japan, 2003 (19). Of the 136 patients, 16 were in stage I, 68 in stage II, 33 in stage III, and 19 in stage IVA. Portal venous invasion, hepatic venous invasion, bile duct invasion, and intrahepatic metastasis were observed in 34 (25.0\%), 10 (7.4\%), 4 (2.9\%), and $40(29.4 \%)$ cases, respectively. In 46 cases, non-cancerous liver tissue showed cirrhosis.

The median follow-up period was 58.5 months (range, 31.6-90.5). Ultrasonography, dynamic computed tomography, magnetic resonance imaging, and laboratory tests

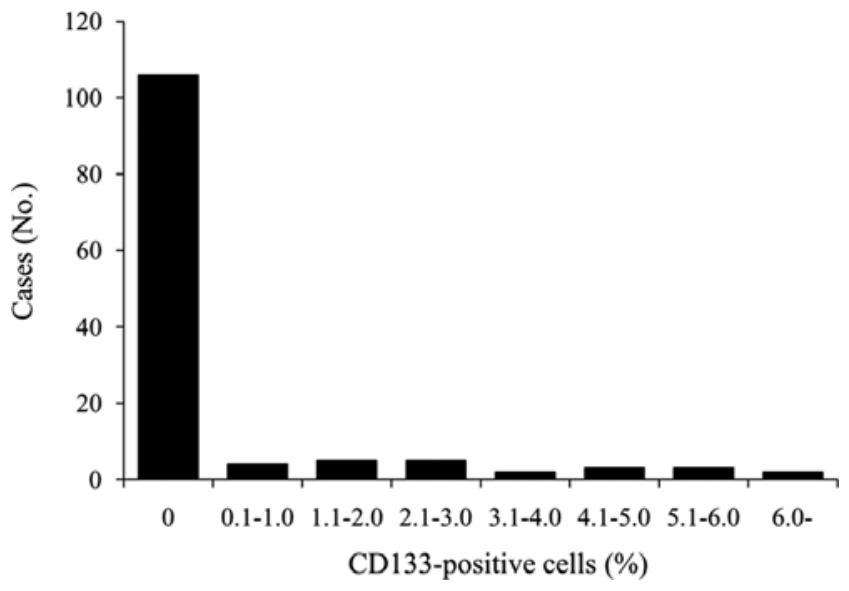

Figure 2. Proportion of CD133-positive tumor cells. CD133-positive tumor cells were counted at high magnification, and then divided by the total number of nuclei of tumor cells counted in the same fields. CD133-positive tumor cells were observed in 30 cases, and the proportion of these cells was $0-9.4 \%$, with the median proportion of $0.64 \%$.

for ( $\alpha$-fetoprotein (AFP), the lens culinaris agglutinin-reactive fraction of AFP (AFP-L3), and protein induced by vitamin $\mathrm{K}$ absence or antagonists (PIVKA-II) were performed every 3 months. HCC recurrence was observed in 93 patients. Informed consent was obtained from each patient according to the Ethics Committee Guidelines of our institution.

Immunohistochemistry. Tissues were fixed in $10 \%$ formalin, embedded in paraffin, cut into 3-4- $\mu \mathrm{m}$ sections, mounted on silane-coated slides, and dried at $58^{\circ} \mathrm{C}$ for $30 \mathrm{~min}$. One section from each tissue was stained with hematoxylin and eosin for histological examination. Immunohistochemical staining was performed on automated immunostainer 

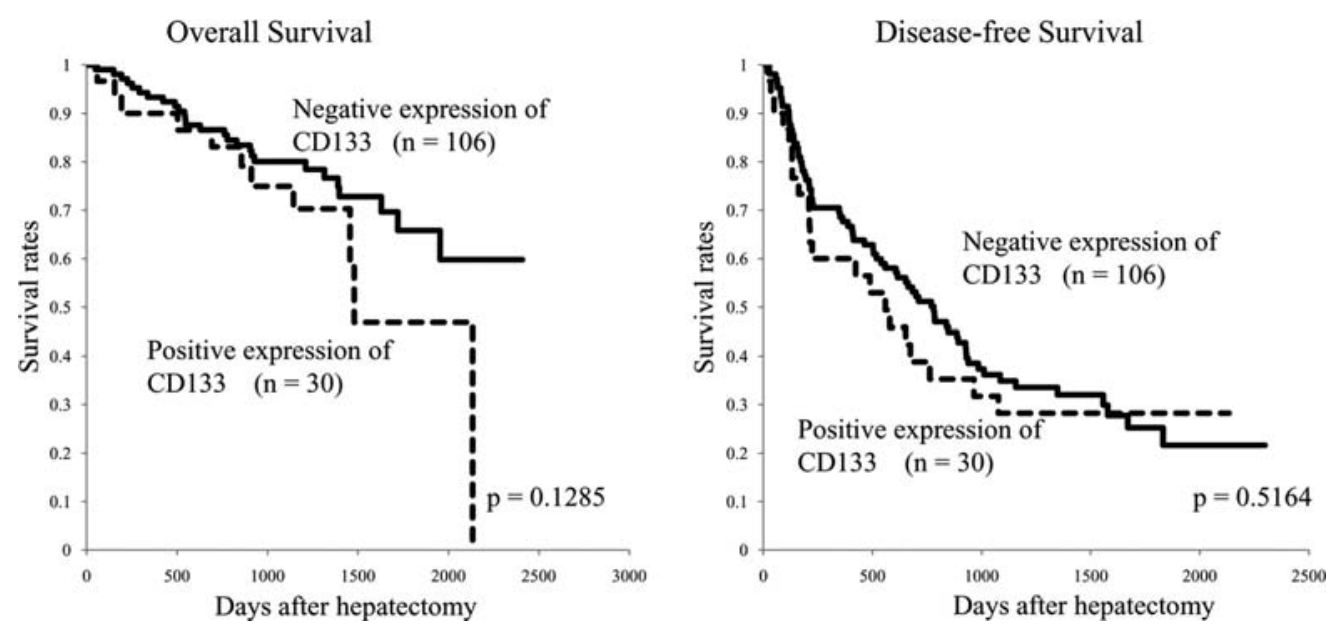

Figure 3. Overall survival and disease-free survival curves of hepatocellular carcinoma patients according to the status of CD133 expression. The differences in survival rates of cases with positive CD133 expression and those with negative CD133 expression were evident, but were not statistically significant. There was no association of disease-free survival between patients showing positive and those showing negative expression of CD133.

(NexES ${ }^{\circledR}$; Ventana Medical Systems, Tucson, AZ, USA) using the Ventana iVIEW DAB Universal kit (Ventana). The slides were deparaffinized with xylene and rehydrated through graded concentrations of ethanol. After the slides were deparaffinized, antigen retrieval was performed for $2.5 \mathrm{~min}$ in a pressure cooker using $1 \mathrm{mmol} / \mathrm{l}$ ethylenediamine tetraacetic acid solution $(\mathrm{pH} 8.0)$. Endogenous peroxidase was blocked with $3 \% \mathrm{H}_{2} \mathrm{O}_{2}$ for $4 \mathrm{~min}$ at $37^{\circ} \mathrm{C}$. Subsequently, the slides were rinsed and incubated at $37^{\circ} \mathrm{C}$ for 32 min with a 1:300 dilution of a rabbit polyclonal anti-CD133 primary antibody (Abcam, Inc., Cambridge, UK). Signal enhancement was performed using the Ventana Amplification kit (Ventana) for 2 incubations of $8 \mathrm{~min}$ each. Slides were then incubated with iVIEW (Ventana) biotinylated goat anti-rabbit immunoglobulin (Ig) G and IgM secondary antibodies for $8 \mathrm{~min}$, followed by incubation in a blocker for $4 \mathrm{~min}$. Subsequently, the slides were counterstained with hematoxylin for $1 \mathrm{~min}$ and rinsed. After the slides were removed from the instrument, they were manually dehydrated and coverslipped.

CD133-positive tumor cells were counted in 10 random and non-overlapping fields at high magnification (x400). The results were expressed as the percentage of the total number of tumor cell nuclei in the fields that showed maximum CD133-positive tumor cells. For statistical analysis, patients were divided into negative (percentage of CD133-positive tumor cells, 0 ) versus positive (percentage of CD133-positive tumor cells $>0$ ) CD133 expression. The entire sections were also screened for features such as cytoplasmic/membranous CD133 expression in tumor cells and that in non-cancerous hepatocytes or the bile duct epithelial cells in the background.

Statistical analysis. Statistical analyses were performed using the StatView J 5.0 software package for Windows (SAS Institute Inc., Cary, NY). Cumulative survival and diseasefree survival rates were calculated using the Kaplan-Meier method, and comparisons between groups were performed by using the log-rank test. The Cox proportional hazards model was used for multivariate analysis. Statistical calculations using standard tests ( $\chi^{2}$ and t-tests) were performed where appropriate. Significance was defined as a P-value of $<0.05$.

\section{Results}

CD133 expression in HCCs. Representative staining images of HCCs are shown in Fig. 1. In the overall series, CD133positive tumor cells were observed in $30(22.1 \%)$ cases, with a median proportion of 0.64 (range: 0-9.4) (Fig. 2). Furthermore, cytoplasmic and membranous expressions of CD133 were identified in $22(16.2 \%)$ and 20 (14.7\%) CD133-positive cases, respectively. There were two patterns of cytoplasmic positivity, diffuse (Fig. 1C) or perinuclear dot-like (Fig. 1D). None of the non-cancerous hepatocytes showed positive immunoreactivity for CD133. CD133 positivity was seen at the endoluminal surface of the bile duct epithelial cells in the background. Positive expression of CD133 was significantly associated with elevated serum AFP levels and histologically high-grade tumor (Table I). Positive cytoplasmic expression of CD133 also significantly correlated with elevated serum AFP levels and histologically high-grade tumor (Table II). With regard to the primary recurrent site, remote metastasis was significantly more frequent in cases showing positive membranous expression of CD133. Portal venous invasion, which included microscopic and macroscopic invasion, was not significantly correlated with CD133 expression. However, both cytoplasmic and membranous expression of CD133 were associated with tumors involving a major branch of the portal vein $(\mathrm{P}=0.0221,0.0104$, respectively).

Overall survival and CD133 expression. Of the 136 patients, 39 died; 33 due to HCC, 3 each due to liver failure and another disease. There was no difference in the overall survival between the cases that showed positive and those that showed negative CD 133 expression (Fig. 3), while the difference in survival rates was significant between the patients with positive and negative cytoplasmic CD133 expression (Fig. 4). The 1- and 3-year survival rates of patients with positive cytoplasmic expression of CD133 were 86.4 
Table I. Comparative analysis of the clinicopathological findings between CD133-positive and CD133-negative groups in HCC patients.

\begin{tabular}{llll}
\hline Clinical factors & $\frac{\mathrm{CD} 133^{+}}{(\mathrm{n}=30)}$ & $\frac{\mathrm{CD} 133^{-}}{(\mathrm{n}=106)}$ & \\
\hline
\end{tabular}

\section{Age}

$\leq 60 />60$

$15 / 15 \quad 50 / 56$

0.7841

Gender

Male/Female

HBsAg

+ -

$17 / 13$

$43 / 63$

HCVAb

$+/-$

$11 / 19$

$43 / 63$

0.7000

Albumin

$\leq 4.0 />4.0(\mathrm{~g} / \mathrm{dl})$

$10 / 20$

$46 / 60$

0.3228

Total bilirubin

$\leq 0.8 />0.8(\mathrm{mg} / \mathrm{dl})$

$25 / 5 \quad 72 / 34$

0.0994

ICGR 15

$\leq 15 />15(\%)$

$18 / 12 \quad 57 / 49$

AFP

$$
\leq 200 />200(\mathrm{ng} / \mathrm{ml})
$$

$16 / 14 \quad 78 / 28$

PIVKA-II

$$
\leq 100 />100(\mathrm{mAU} / \mathrm{ml})
$$

$57 / 48$

Recurrence

Yes/No

$72 / 34$

0.8291

Primary recurrence site Liver/Remote

$14 / 7 \quad 58 / 14$

0.1804

Anatomic resection ${ }^{\mathrm{a}}$ Yes/No

$74 / 32$

0.4636

Tumor morphology ${ }^{\mathrm{b}}$

Nodular/Extensive

$15 / 15$

$65 / 41$

0.2660

Tumor number

Single/Multiple

Tumor size

$\leq 10 />10(\mathrm{~cm})$

$18 / 12 \quad 76 / 30$

0.2208

$94 / 12$

0.0938

Tumor grade Well/Mod/Por

$1 / 10 / 19 \quad 6 / 78 / 21^{\mathrm{c}} \quad<0.0001$

Portal venous invasion + $11 / 19 \quad 23 / 83$

0.0946

Hepatic venous invasion + -

$6 / 100$

0.1552

Bile duct invasion + -

\begin{tabular}{|c|c|c|c|}
\hline & CD133+ & CD133- & \\
\hline Clinical factors & $(n=30)$ & $(n=106)$ & p-value \\
\hline \multicolumn{4}{|c|}{ Intrahepatic metastasis } \\
\hline$+/-$ & $11 / 19$ & $29 / 77$ & 0.3232 \\
\hline \multicolumn{4}{|l|}{ Cirrhosis } \\
\hline$+/-$ & $11 / 19$ & $35 / 71$ & 0.7093 \\
\hline
\end{tabular}

Table I. Continued.

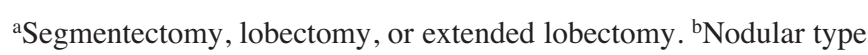

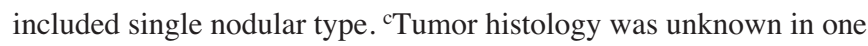
case. HBsAg, hepatitis B virus antigen; HCVAb, hepatitis C virus antibody; ICG R15, indocyanine green retention rate at $15 \mathrm{~min}$; AFP, $\alpha$-fetoprotein; PIVKA-II, protein induced by vitamin $\mathrm{K}$ absence or antagonists; mod, moderate; por, poor.

and $64.4 \%$, respectively, while those of patients with negative cytoplasmic expression of CD133 were 93.8 and $66.6 \%$, respectively. Membranous expression of CD133 had no correlation with the overall survival: the 1- and 3-year survival rates of the patients with positive membranous expression of CD133 were 95.0 and $78.8 \%$, respectively, while those of patients with negative membranous expression of CD133 were 95.0 and $79.7 \%$, respectively $(P=0.5054)$. Univariate analysis revealed that preoperative serum albumin, AFP level, PIVKA-II level, tumor number, tumor size, portal venous invasion, hepatic venous invasion, intrahepatic metastases, and cytoplasmic expression of CD133 were significant risk factors (Table III). Multivariate analysis revealed that preoperative albumin level, AFP level, PIVKA-II level, and portal venous invasion, but not cytoplasmic expression of CD133, were independent risk factors for patient survival (Table IV).

The differences in the survival rate of the 52 cases with stage III and IVA HCC were more significant between patients showing positive and those showing negative cytoplasmic expression of CD133 ( $\mathrm{P}=0.0092)$, compared to the differences in patients with stage I, II, III, and IVA HCC (Fig. 5). In the patients with stage III and IVA HCC, the 1- and 3 -year survival rates of cases showing positive cytoplasmic expression of CD133 were 70.0 and $16.7 \%$, respectively, while those showing negative cytoplasmic expression were 82.9 and $69.4 \%$, respectively. Univariate analysis revealed that preoperative serum albumin, AFP level, tumor size, portal venous invasion, and cytoplasmic expression of CD133 were important risk factors (Table V). Multivariate analysis revealed that preoperative albumin level was the only independent risk factor for patient survival (Table VI). Among the factors related to tumor aggressiveness, cytoplasmic expression of CD133 was found to be most significantly associated with overall survival, although the difference was not statistically significant $(\mathrm{P}=0.0681)$.

Disease-free survival and CD133 expression. The difference in the disease-free survival was not significant between 
Table II. Comparative analysis of the clinicopathological findings and CD133 status in HCC patients.

\begin{tabular}{|c|c|c|c|c|c|c|}
\hline \multirow[b]{2}{*}{ Clinical Factors } & \multicolumn{2}{|c|}{ CD133 cytoplasmic } & \multirow[b]{2}{*}{ p-value } & \multicolumn{2}{|c|}{ CD133 menbranous } & \multirow[b]{2}{*}{ p-value } \\
\hline & $\begin{array}{l}\text { Positive } \\
(n=22)\end{array}$ & $\begin{array}{l}\text { Negative } \\
(n=114)\end{array}$ & & $\begin{array}{l}\text { Positive } \\
(n=20)\end{array}$ & $\begin{array}{l}\text { Negative } \\
(n=116)\end{array}$ & \\
\hline \multicolumn{7}{|l|}{ Age } \\
\hline$\leq 60 />60$ & $10 / 12$ & $55 / 59$ & 0.8104 & $14 / 6$ & $51 / 65$ & 0.0313 \\
\hline \multicolumn{7}{|l|}{ Gender } \\
\hline Male/Female & $17 / 5$ & $95 / 19$ & 0.4948 & $16 / 4$ & $96 / 20$ & 0.7650 \\
\hline \multicolumn{7}{|l|}{ HBsAg } \\
\hline$+/-$ & $13 / 9$ & $47 / 67$ & 0.1224 & $13 / 7$ & $47 / 69$ & 0.0417 \\
\hline \multicolumn{7}{|l|}{$\mathrm{HCVAb}$} \\
\hline$+/-$ & $9 / 13$ & $45 / 69$ & 0.8997 & $6 / 14$ & $48 / 68$ & 0.3368 \\
\hline Albumin & & & & & & \\
\hline$\leq 4.0 />4.0(\mathrm{~g} / \mathrm{dl})$ & $9 / 13$ & $47 / 67$ & 0.9778 & $7 / 13$ & $49 / 67$ & 0.5434 \\
\hline $\begin{array}{l}\text { Total bilirubin } \\
\leq 0.8 />0.8(\mathrm{mg} / \mathrm{dl})\end{array}$ & $17 / 5$ & $80 / 34$ & 0.5004 & $17 / 3$ & $80 / 36$ & 0.1431 \\
\hline $\begin{array}{l}\text { ICGR15 } \\
\qquad \leq 15 />15(\%)\end{array}$ & $14 / 8$ & $61 / 53$ & 0.3819 & $12 / 8$ & $63 / 53$ & 0.6366 \\
\hline $\begin{array}{l}\text { AFP } \\
\leq 200 />200(\mathrm{ng} / \mathrm{ml})\end{array}$ & $10 / 12$ & $84 / 30$ & 0.0087 & $12 / 8$ & $82 / 34$ & 0.3393 \\
\hline $\begin{array}{l}\text { PIVKA-II } \\
\leq 100 />100(\mathrm{mAU} / \mathrm{ml})\end{array}$ & $9 / 13$ & $61 / 52$ & 0.2615 & $9 / 11$ & $61 / 54$ & 0.5064 \\
\hline $\begin{array}{l}\text { Recurrence } \\
\text { Yes/No }\end{array}$ & $17 / 5$ & $76 / 38$ & 0.3273 & $13 / 7$ & $80 / 36$ & 0.7247 \\
\hline $\begin{array}{l}\text { Primary recurrence site } \\
\text { Liver/Remote }\end{array}$ & $10 / 7$ & $59 / 17$ & 0.9176 & $7 / 6$ & $65 / 15$ & 0.0284 \\
\hline $\begin{array}{l}\text { Anatomic resection }{ }^{\mathrm{a}} \\
\text { Yes/No }\end{array}$ & $16 / 6$ & $81 / 33$ & 0.8737 & $16 / 4$ & $81 / 35$ & 0.3529 \\
\hline $\begin{array}{l}\text { Tumor morphology } \\
\text { Nodular/Extensive }\end{array}$ & $11 / 11$ & $69 / 45$ & 0.3584 & $11 / 9$ & $69 / 47$ & 0.7068 \\
\hline $\begin{array}{l}\text { Tumor number } \\
\text { Single/Multiple }\end{array}$ & $12 / 10$ & $82 / 32$ & 0.1061 & $13 / 7$ & $81 / 35$ & 0.6661 \\
\hline $\begin{array}{l}\text { Tumor size } \\
\leq 10 />10(\mathrm{~cm})\end{array}$ & $16 / 6$ & $101 / 13$ & 0.0493 & $16 / 4$ & $101 / 15$ & 0.3997 \\
\hline $\begin{array}{l}\text { Tumor grade } \\
\text { Well/Mod/Por }\end{array}$ & $1 / 7 / 14$ & $6 / 81 / 26^{c}$ & 0.0006 & $0 / 7 / 13$ & $7 / 81 / 27^{c}$ & 0.0007 \\
\hline $\begin{array}{l}\text { Portal venous invasion } \\
+/-\end{array}$ & $8 / 14$ & $26 / 88$ & 0.1788 & $8 / 12$ & $26 / 90$ & 0.0935 \\
\hline $\begin{array}{l}\text { Hepatic venous invasion } \\
+/-\end{array}$ & $3 / 19$ & $7 / 107$ & 0.2175 & $3 / 17$ & $7 / 109$ & 0.1560 \\
\hline $\begin{array}{l}\text { Bile duct invasion } \\
+/-\end{array}$ & $1 / 21$ & $3 / 111$ & 0.6267 & $1 / 19$ & $3 / 113$ & 0.5552 \\
\hline $\begin{array}{l}\text { Intrahepatic metastasis } \\
+/-\end{array}$ & $10 / 12$ & $30 / 84$ & 0.0713 & $6 / 14$ & $34 / 82$ & 0.9502 \\
\hline $\begin{array}{l}\text { Cirrhosis } \\
+/-\end{array}$ & $10 / 12$ & $36 / 78$ & 0.2079 & $7 / 13$ & $39 / 77$ & 0.9042 \\
\hline
\end{tabular}

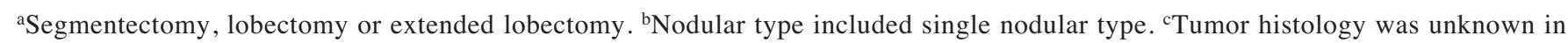
one case. HBsAg, hepatitis B virus antigen; HCVAb, hepatitis C virus antibody; ICG R15, indocyanine green retention rate at 15 min; AFP, $\alpha$-fetoprotein; PIVKA-II, protein induced by vitamin K absence or antagonists; mod, moderate; por, poor. 

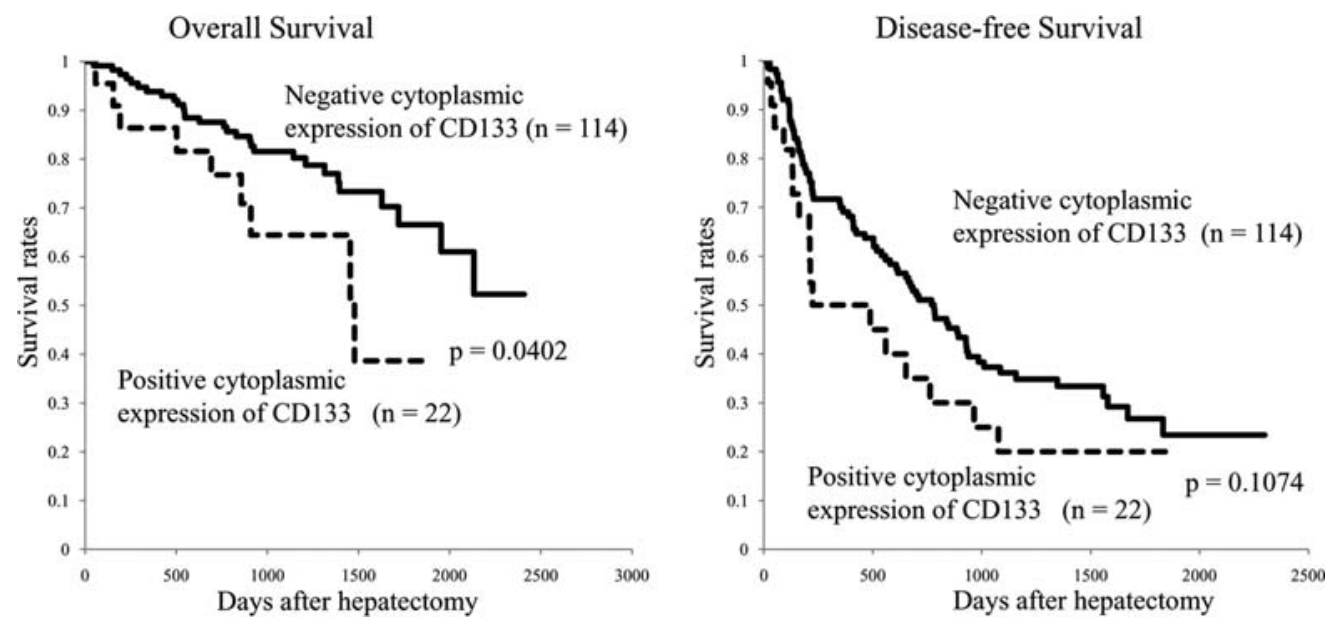

Figure 4. Overall survival and disease-free survival curves of hepatocellular carcinoma patients with positive and negative cytoplasmic expression of CD133. Overall survival rates of patients with negative cytoplasmic expression of CD133 were significantly higher than those with positive expression of CD133. The differences in disease-free survival rates between cases with positive versus those with negative cytoplasmic expression of CD133 were evident, but not statistically significant.

Table III. Univariate analysis of the factors affecting overall survival and disease-free survival.

\begin{tabular}{ccc}
\hline & $\begin{array}{c}\text { Overall } \\
\text { survival } \\
\text { N-value }\end{array}$ & $\begin{array}{c}\text { Disease-free } \\
\text { survival } \\
\text { Novalue }\end{array}$ \\
\hline
\end{tabular}

\section{Age (year)}

$\leq 60 />60$

$65 / 71$

0.6365

0.0083

Gender

Male/Female

$112 / 24$

0.2555

0.9671

HBsAg

$+/-$

$60 / 76$

0.0992

0.0003

$\mathrm{HCV}$

$+/-$

0.5323

0.0715

Albumin (g/dl) $\leq 4.0 />4.0$ $56 / 80$

0.0009

0.0020

Total bilirubin $(\mathrm{mg} / \mathrm{dl})$

$\leq 0.8 />0.8$

97/39

0.1546

0.4222

ICGR15 (\%)

$$
\leq 15 />15
$$

0.7760

0.1301

AFP (ng/ml)

$$
\leq 200 />200
$$

$94 / 42<0.0001$

0.1247

PIVKA2 (mAU/ml)

$$
\leq 100 />100
$$

0.0005

0.0064

Tumor morphology

Nodular/Extensive

$80 / 56 \quad 0.9848$

0.5315

Tumor number

\begin{tabular}{|c|c|c|c|}
\hline & No. & $\begin{array}{l}\text { Overall } \\
\text { survival } \\
\text { p-value }\end{array}$ & $\begin{array}{l}\text { Disease-free } \\
\text { survival } \\
\text { p-value }\end{array}$ \\
\hline \multicolumn{4}{|l|}{ Tumor size $(\mathrm{cm})$} \\
\hline$\leq 10 />10$ & $117 / 19$ & 0.0005 & $<0.0001$ \\
\hline \multicolumn{4}{|l|}{ Histology } \\
\hline Well + Mod/Por & $95 / 40$ & 0.1011 & 0.0091 \\
\hline \multicolumn{4}{|c|}{ Portal vein invasion } \\
\hline$+/-$ & $34 / 102$ & $<0.0001$ & $<0.0001$ \\
\hline \multicolumn{4}{|c|}{ Hepatic vein invasion } \\
\hline$+/-$ & $10 / 126$ & 0.0010 & $<0.0001$ \\
\hline \multicolumn{4}{|c|}{ Intrahepatic metastasis } \\
\hline$+/-$ & $40 / 96$ & 0.0110 & $<0.0001$ \\
\hline \multicolumn{4}{|l|}{ Cirrhosis } \\
\hline$+/-$ & $46 / 90$ & 0.2779 & 0.0656 \\
\hline \multicolumn{4}{|l|}{ CD133 cytoplasmic } \\
\hline$+/-$ & $22 / 114$ & 0.0402 & 0.1074 \\
\hline \multicolumn{4}{|c|}{$\begin{array}{l}\text { HBsAg, hepatitis B virus antigen; HCVAb, hepatitis } \mathrm{C} \text { virus anti- } \\
\text { body; ICG R15, indocyanine green retention rate at } 15 \mathrm{~min} \text {; AFP, } \alpha \text { - } \\
\text { fetoprotein; PIVKA-II, protein induced by vitamin } \mathrm{K} \text { absence or } \\
\text { antagonists; mod, moderate; por, poor. }\end{array}$} \\
\hline
\end{tabular}

Single/Multiple
Table III. Continued.

patients with positive and those with negative CD133 expression (Fig. 3). Positive membranous expression of CD133 and positive cytoplasmic expression of CD133 were not associated with disease-free survival $(\mathrm{P}=0.7429$, $\mathrm{P}=0.1074$, respectively). Although the difference was not 
Table IV. Multivariate analysis of the factors affecting overall survival.

\begin{tabular}{lccc}
\hline & p-value & Risk ratio & 95\% Confidence interval \\
\hline Albumin $\leq 4.0(\mathrm{~g} / \mathrm{dl})$ & 0.0016 & 3.663 & $1.634-8.929$ \\
AFP $>200(\mathrm{ng} / \mathrm{ml})$ & 0.0017 & 3.322 & $1.571-7.024$ \\
PIVKA2 $>100(\mathrm{mAU} / \mathrm{ml})$ & 0.0175 & 2.793 & $1.197-6.515$ \\
Tumor number multiple & 0.9589 & 1.025 & $0.398-2.639$ \\
Tumor size $>10(\mathrm{~cm})$ & 0.4047 & 0.641 & $0.225-1.826$ \\
Portal vein invasion $(+)$ & 0.0313 & 2.433 & $1.083-5.464$ \\
Hepatic vein invasion $(+)$ & 0.7043 & 1.312 & $0.323-5.348$ \\
Intrahepatic metastasis $(+)$ & 0.6651 & 1.238 & $0.470-3.257$ \\
CD133 cytoplasmic $(+)$ & 0.3108 & 1.550 & $0.664-3.610$ \\
\hline
\end{tabular}

AFP, $\alpha$-fetoprotein; PIVKA-II, protein induced by vitamin $\mathrm{K}$ absence or antagonists.
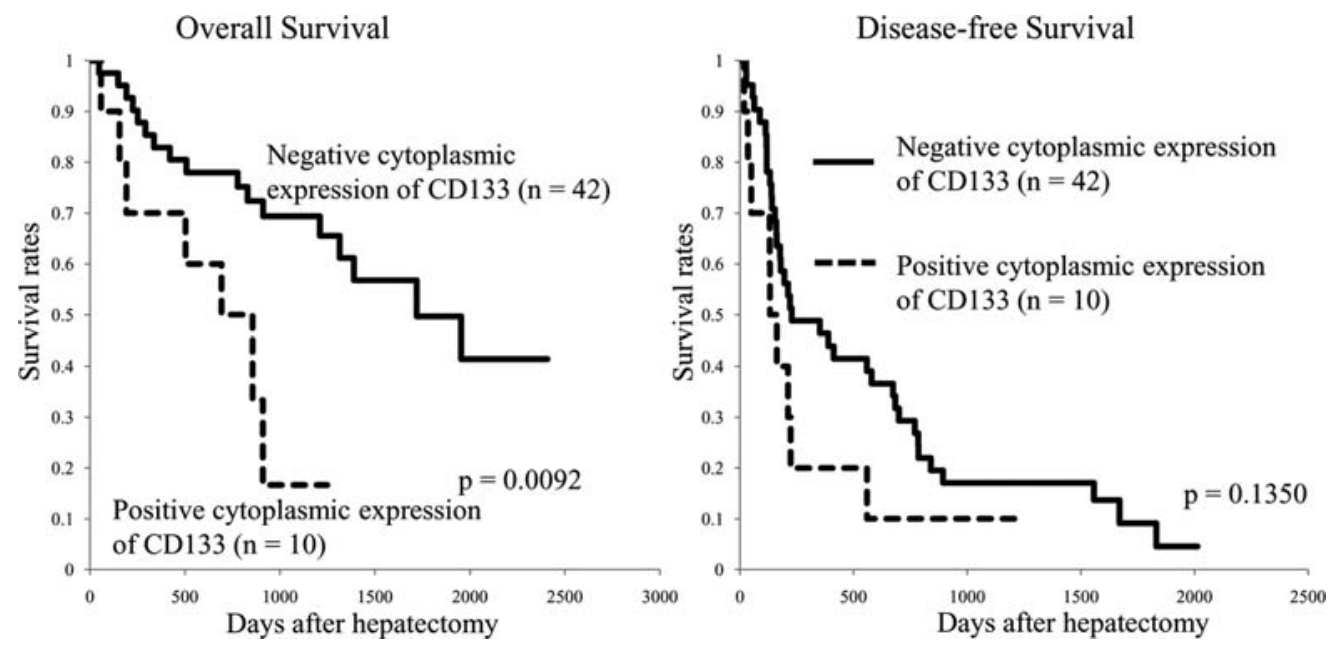

Figure 5. Overall survival and disease-free survival curves in hepatocellular carcinoma patients in stage III and IVA according to the cytoplasmic expression patterns of CD133. The differences were more significant in survival rates between patients with positive and those with negative cytoplasmic expression of CD133, compared to the difference in patients with stage I, II, III, and IVA HCC. The differences in the disease-free survival rates between patients with CD133-positive and those with CD133-negative cells were evident, but not statistically significant.

significant, patients with negative cytoplasmic expression showed a higher disease-free survival rate: the 1- and 3-year disease-free survival rates of the patients with positive cytoplasmic expression of CD133 were $50.0 \%$ and $20.0 \%$, respectively, while those of patients with negative cytoplasmic expression of CD133 were 69.0 and $36.1 \%$, respectively (Fig. 4).

Univariate analysis revealed that age, HBV infection, preoperative serum albumin, PIVKA-II level, tumor number, tumor size, histological grade of tumor, portal venous invasion, hepatic venous invasion, and intrahepatic metastases were significant risk factors (Table III). Multivariate analysis revealed that preoperative albumin level $(\mathrm{P}=0.0214$, risk ratio, $1.792,95 \%$ confidence interval, 1.091-2.950) and tumor size $(\mathrm{P}=0.0328$, risk ratio, $2.237,95 \%$ confidence interval, 1.068-4.685) were independent risk factors for disease-free survival.
In the 52 cases with stage III and IVA HCCs, preoperative serum albumin, PIVKA-II level, tumor size, histological tumor grade, portal venous invasion, and hepatic venous invasion were found to be significant risk factors by univariate analysis (Table $\mathrm{V}$ ), and preoperative albumin level $(\mathrm{P}=0.0180$, risk ratio, $2.381,95 \%$ confidence interval, $1.160-4.878)$ and PIVKA-II level $(\mathrm{P}=0.0174$, risk ratio, $2.506,95 \%$ confidence interval, 1.175-5.346) were found to be independent risk factor for disease-free survival by multivariate analysis.

\section{Discussion}

The present study shows that cytoplasmic expression of CD133 in HCC is associated with elevated serum AFP level, histologically high-grade tumor, and tumor invasion to the major branch of the portal vein. Moreover, positive 
Table V. Univariate analysis of the factors affecting overall survival and disease-free survival in stage III and IVA HCC patients.

\begin{tabular}{|c|c|c|c|}
\hline & No. & $\begin{array}{l}\text { Overall } \\
\text { survival } \\
\text { p-value }\end{array}$ & $\begin{array}{c}\text { Disease-free } \\
\text { survival } \\
\text { p-value }\end{array}$ \\
\hline \multicolumn{4}{|l|}{ Age (year) } \\
\hline$\leq 60 />60$ & $26 / 26$ & 0.8781 & 0.1747 \\
\hline \multicolumn{4}{|l|}{ Gender } \\
\hline Male/Female & $43 / 9$ & 0.1822 & 0.6316 \\
\hline \multicolumn{4}{|l|}{ HBsAg } \\
\hline$+/-$ & $29 / 23$ & 0.5165 & 0.0604 \\
\hline \multicolumn{4}{|l|}{$\mathrm{HCV}$} \\
\hline$+/-$ & $16 / 36$ & 0.6117 & 0.8400 \\
\hline \multicolumn{4}{|l|}{ Albumin (g/dl) } \\
\hline$\leq 4.0 />4.0$ & $24 / 28$ & 0.0268 & 0.0082 \\
\hline $\begin{array}{l}\text { Total bilirubin }(\mathrm{mg} / \mathrm{dl} \\
\leq 0.8 />0.8\end{array}$ & $40 / 12$ & 0.5036 & 0.9727 \\
\hline $\begin{array}{l}\text { ICGR15 }(\%) \\
\leq 15 />15\end{array}$ & $34 / 18$ & 0.5185 & 0.7273 \\
\hline $\begin{array}{l}\operatorname{AFP}(\mathrm{ng} / \mathrm{ml}) \\
\leq 200 />200\end{array}$ & $26 / 26$ & 0.0145 & 0.3582 \\
\hline $\begin{array}{l}\text { PIVKA2 (mAU/ml) } \\
\quad \leq 100 />100\end{array}$ & $18 / 34$ & 0.0903 & 0.0099 \\
\hline $\begin{array}{l}\text { Tumor morphology } \\
\text { Nodular/Extensive }\end{array}$ & $24 / 28$ & 0.9489 & 0.1575 \\
\hline $\begin{array}{l}\text { Tumor number } \\
\text { Single/Multiple }\end{array}$ & $15 / 37$ & 0.6983 & 0.4865 \\
\hline $\begin{array}{l}\text { Tumor size }(\mathrm{cm}) \\
\leq 10 />10\end{array}$ & $38 / 14$ & 0.0137 & 0.0002 \\
\hline \multicolumn{4}{|l|}{ Histology } \\
\hline $\begin{array}{l}\text { Portal vein invasion } \\
+/-\end{array}$ & $27 / 25$ & 0.0196 & 0.0141 \\
\hline $\begin{array}{l}\text { Hepatic vein invasion } \\
+/-\end{array}$ & $10 / 42$ & 0.1389 & 0.0442 \\
\hline $\begin{array}{l}\text { Intrahepatic metastasi } \\
+/-\end{array}$ & $35 / 17$ & 0.4994 & 0.2392 \\
\hline $\begin{array}{l}\text { Cirrhosis } \\
+/-\end{array}$ & $19 / 33$ & 0.6495 & 0.8355 \\
\hline $\begin{array}{l}\text { CD133 cytoplasmic } \\
+/-\end{array}$ & $10 / 42$ & 0.0092 & 0.1350 \\
\hline $\begin{array}{l}\text { HBsAg, hepatitis B vir } \\
\text { body; ICG R15, indocy; } \\
\text { fetoprotein; PIVKA-II, } \\
\text { antagonists; mod, mode }\end{array}$ & $\begin{array}{l}\text { tigen; } \mathrm{H} \\
\text { green } \mathrm{r} \\
\text { ein indu } \\
\text { por, po }\end{array}$ & $\begin{array}{l}\mathrm{Ab} \text {, hep } \\
\text { tion rate } \\
\text { by vitar }\end{array}$ & $\begin{array}{l}\text { is } \mathrm{C} \text { virus anti- } \\
5 \mathrm{~min} \text {; } \mathrm{AFP}, \alpha- \\
\mathrm{K} \text { absence or }\end{array}$ \\
\hline
\end{tabular}

cytoplasmic expression of CD133 was found to be an important risk factor for overall survival, especially in patients with stage III and IVA HCC.

The study demonstrated that CD133 expression is associated with the clinicopathological factors, including preoperative serum AFP level and poorly differentiated tumors. The results are consistent with those of another study (17), with respect to the association between patients with CD133 positive and negative expression for overall survival and the difference in elevated serum AFP level and highgrade tumor. Our results were different with regard to the association between CD133 expression and disease-free survival. However, Salnikov et al (18) reported that there was no correlation between the amount of CD133 positive cells and clinicopathological status of HCC patients. Moreover, in these previous studies, almost all cases had CD133-positive tumor cells, whereas in our study, not all the cases were CD133 positive. The discrepancies may be have arisen due to the differences in the antibody used, the quality of tissue samples analyzed, the immunostaining protocols and scoring systems, the number of cases, and the difference in the tumor grading and staging of the participants. Although several studies showed that CD133-positive cells separated from HCC cell lines have the ability to self-renew and proliferate, suggesting that these cells are putative stem/progenitor cells $(15,16,20)$, further investigation is required to reveal the significance and clinical impact of CD133 expression in HCC patients.

CD133 antigen was identified as a cell surface antigen on CD34+ hematopoietic stem cells (14). CD133 localizes to the plasma membrane protrusions at the apical surface of cells (21). However, in normal retina and some epithelial and nonepithelial malignancies, cytoplasmic localization of CD133 was observed $(22,23)$. Diffuse cytoplasmic staining was observed in the retina and gastrointestinal stromal tumors, and perinuclear dot-like staining pattern was observed in the glioblastoma multiforme, myelogenous leukemia, pancreatic ductal adenocarcinoma, and ovarian cancer. Cytoplasmic expression of CD133 was associated with the patient survival in ovarian cancers, although the difference was not statistically significant (23). There was no description about the subcellular localization of CD133 in HCC, and this is the first study analyzing the expression and subcellular distribution of CD133 antigen in HCC tissues from a large series of patients who underwent curative hepatic resection. We found that CD133 expression might be observed both in the cytoplasm and membrane of tumor cells, and the correlation of CD133 expression to patient survival was clearly demonstrated.

Any protein having different subcellular localization may have a specific function, although the physiological role of CD133 is yet unknown. CD133 has splice variants in glial cells (24), and abnormal DNA methylation of CD133 has been observed in colorectal tumors and glioblastomas (25). Molecular genetic analysis of autosomal recessive retinal degeneration indicated that the affected individuals had a frameshift mutation in prominin 1 (synonym for CD133) with premature termination of translation, and the truncated protein cannot be transported to the cell surface (26). Absence of membranous CD133 expression, as observed in HCCs 
Table VI. Multivariate analysis of the factors affecting overall survival in stage III and IVA HCC patients.

\begin{tabular}{lccc}
\hline & p-value & Risk ratio & 95\% Confidence interval \\
\hline Albumin $\leq 4.0(\mathrm{~g} / \mathrm{dl})$ & 0.0338 & 2.577 & $1.075-6.173$ \\
AFP $>200(\mathrm{ng} / \mathrm{ml})$ & 0.1348 & 2.060 & $0.799-5.315$ \\
Tumor size $>10(\mathrm{~cm})$ & 0.7332 & 1.189 & $0.439-3.221$ \\
Portal vein invasion $(+)$ & 0.2675 & 1.745 & $0.652-4.673$ \\
CD133 cytoplasmic $(+)$ & 0.0681 & 2.604 & $0.931-7.299$ \\
\hline
\end{tabular}

AFP, $\alpha$-fetoprotein.

in this study, may probably indicate the accumulation of truncated CD133 protein, internalization of CD133 protein on membranes that may result in rapid degradation. This phenomenon has been already observed for the epidermal growth factor receptor in cultured cells (27). The failure of transportation and insertion of newly synthesized molecules within the Golgi apparatus into the membranes is also discussed as a possible mechanism (28).

In this study, a significant association was observed between cytoplasmic expression of CD133 and overall survival of patients with HCC in advanced stage. There are two principal characteristics that contribute to the high HCC recurrence rate: multicentric carcinogenicity and hematogenous metastasis to the liver and remote organs $(4,29)$. The prognosis of small HCCs after hepatic resection differs depending on the presence of liver cirrhosis. Most intrahepatic recurrences of small HCCs after hepatectomy are considered to be de novo metachronous tumors (30). Multicentric carcinogenesis due to liver cirrhosis in the remnant liver is an important factor for the postresection survival of patients in an earlier stage of HCC (31). The disease-free survival of patients who underwent resection of large HCCs was shorter than that of the patients with small HCCs (32). Because vascular invasion was more frequently observed in patients with large HCCs, the contribution of hematogenous spread of tumor cells was comparatively higher in the patients with HCC in advanced stage. It has been reported that the recurrence of HCCs might be caused by hematogenous spread of tumor cells among the patients exceeded the Milan criteria, these patients may have unfavorable prognosis compared to those within the Milan criteria who developed the recurrence of HCC that might be caused by de novo metachronous tumors (33). As per the cancer stem cell theory, hematogenous metastasis in HCC cases might be more related with recurrence induced by the cancer stem cell, because cytoplasmic expression of CD133 was associated with tumor aggressiveness; elevated serum AFP level, histologically high-grade tumor, and vascular invasion, whereas multistep dedefferentiation would be considered important for multicentric carcinogenesis. Cytoplasmic, not membranous, staining of CD133 may be a useful marker of cancer stem cell in HCC. Further investigation is warranted in order to conclude that subcellular localization of CD133 is a key feature of recognition of cancer stem cells in certain cancers.
In conclusion, positive cytoplasmic expression of CD133 represented the risk of poor prognosis, especially in patients with advanced stage HCC. Cytoplasmic expression of CD133 can serve as a marker for clinical prognosis of HCC patients.

\section{Acknowledgements}

The authors thank the staff of General Surgery, Graduate School of Medicine, Hokkaido University, and the Department of Surgical Pathology, Hokkaido University Hospital, Sapporo, Japan, for their cooperation and Ms. N. Kobayashi, Mr. J. Moriya, and Mr. K. Marukawa for technical assistance.

\section{References}

1. Parkin DM, Bray F, Ferlay J and Pisani P: Global Cancer Statistics, 2002. CA Cancer J Clin 55: 74-108, 2005.

2. Takata M, Yamanaka N, Tanaka T, et al: What patients can survive disease free after complete resection for hepatocellular carcinoma? A multivariate analysis. Jpn J Clin Oncol 30: 75-81, 2000.

3. Poon RT, Fan ST, Ng IO, Lo CM, Liu CL and Wong J: Different risk factors and prognosis for early and late intrahepatic recurrence after resection of hepatocellular carcinoma. Cancer 89: 500-507, 2000.

4. Ikeda K, Arase Y, Kobayashi M, et al: Significance of multicentric cancer recurrence after potentially curative ablation of hepatocellular carcinoma: a longterm cohort study of 892 patients with viral cirrhosis. J Gastroenterol 38: 865-876, 2003.

5. Reya T, Morrison SJ, Clarke MF and Weissman IL: Stem cells, cancer and cancer stem cells. Nature 414: 105-111, 2001.

6. Bonnet D and Dick JE: Human acute myeloid leukemia is organized as a hierarchy that originates from a primitive hematopoietic cell. Nat Med 3: 730-737, 1997.

7. Singh SK, Clarke ID, Terasaki M, Bonn VE, Hawkins C, Squre J and Dirks PB: Identification of a cancer stem cell in human brain tumors. Cancer Res 63: 5821-5828, 2003.

8. Al-Hajj M, Wicha MS, Benito-Hernandez A, Morrison SJ and Clarke MF: Prospective identification of tumorigenic breast cancer cells. Proc Natl Acad Sci USA 100: 3983-3988, 2003.

9. Hermann PC, Huber SL, Herrler T, et al: Distinct populations of cancer stem cells determine tumor growth and metastatic activity in human pancreatic cancer. Cell Stem Cell 1: 313-323, 2007.

10. Eramo A, Lotti F, Sette G, et al: Identification and expansion of the tumorigenic lung cancer stem cell population. Cell Death Differ 15: 504-514, 2008.

11. Ricci-Vitani L, Lombardi DG, Pilozzi E, Biffoni M, Torado M, Peschle C and De Maria R: Identification and expansion of human colon-cancer-initiating cells. Nature 445: 111-115, 2007.

12. O'Brien CA, Pollett A, Gallinger S and Dick JE: A human colon cancer cell capable of initiating tumour growth in immunodeficient mice. Nature 445: 106-110, 2007. 
13. Ma S, Lee TK, Zheng BJ, Chan KW and Guan XY: CD133 HCC cancer stem cells confer chemoresistance by preferential expression of the Akt/PKB survival pathway. Oncogene 27: 1749-1758, 2008.

14. Yin AH, Miraglia S, Zanjani ED, et al: AC133, a novel marker for human hematopoietic stem and progenitor cells. Blood 90: 5002-5012, 1997.

15. Suetsugu A, Nagaki M, Aoki H, Motohashi T, Kunisada T and Moriwaki $\mathrm{H}$ : Characterization of $\mathrm{CD}_{133^{+}}$hepatocellular carcinoma cells as cancer stem/progenitor cells. Biochem Biophys Res Commun 351: 820-824, 2006.

16. Yin $\mathrm{S}$, Li J, Hu C, et al: CD133 positive hepatocellular carcinoma cells possess high capacity for tumorigenicity. Int J Cancer 120: 1444-1450, 2007.

17. Song W, Li H, Tao K, et al: Expression and clinical significance of the stem cell marker CD133 in hepatocellular carcioma. Int J Clin Pract 62: 1212-1218, 2008.

18. Salnikov AV, Kusumawidjaja G, Rausch V, et al: Cancer stem cell marker expression in hepatocellular carcinoma and liver metastases is not sufficient as single prognostic paramater. Cancer Lett 275: 185-193, 2008.

19. Liver Cancer Study Group of Japan. General Rules of the Clinica and Pathological Study of Primary Liver Cancer. 2nd edition. Kanehara \& Co., Ltd., Tokyo, 2003.

20. Ma S, Chan KW, Hu L, et al: Identification and characterization of tumorigenic liver cancer stem/progenitor cells. Gastroenterology 132: 2542-2556, 2007.

21. Corbeil D, Röper K, Hellwig A, et al: The human AC133 hematopoietic stem cell antigen is also expressed in epithelial cells and targeted to plasma membrane protrusions. J Biol Chem 275: 5512-5520, 2000

22. Immervoll H, Hoem D, Sakariassen PØ, Steffensen OJ and Molven A: Expression of the stem cell marker CD133 in pancreas and pancreatic ductal adenocarcinomas. BMC Cancer 8 : 48-62, 2008

23. Ferrandina G, Martinelli E, Petrillo M, Prisco MG, Zannoni G, Sioletic S and Scanbia G: CD133 antigen expression in ovarian cancer. BMC Cancer 9: 221-230, 2009.
24. Corbeil D, Joester A, Fargeas C, et al: Expression of distinct splice variants of the stem cell marker prominin-1 (CD133) in glial cells. Glia 57: 860-874, 2009.

25. Yi JM, Tsai HC, Glöckner SC, et al: Abnormal DNA methylation of CD133 in colorectal and glioblastoma tumors. Cancer Res 68: 8094-8103, 2008.

26. Maw MA, Corbeil D, Koch J, et al: A frameshift mutation in prominin (mouse)-like 1 causes human retinal degeneration. Hum Mol Genet 9: 27-34, 2000.

27. Begunot L, Lyall RM, Willingham MC and Pastan I: Downregulation of the epidermal growth factor receptor in $\mathrm{KB}$ cells is due to receptor internalizaiton and subsequent degradation in lysosomes. Proc Natl Acad Sci USA 81: 2384-2388, 1984.

28. Piyathilake CJ, Frost AR, Manne U, Weiss H, Bell WC, Heimburger DC and Grizzle WE: Differential expression of growth factors in squamous cell carcinoma and precancerous lesions of the lung. Clin Cancer Res 8: 734-744, 2002.

29. Lise M, Bacchetti S, Da Pian P, Nitti D, Pilati PL and Pigato P: Prognostic factors affecting long term outcome after liver resection for hepatocellular carcinoma: results in a series of 100 Italian patients. Cancer 82: 1028-1036, 1998.

30. Adachi E, Maeda T, Matsumata T, Shirabe K, Kinukawa N, Sugimachi K and Tsuneyoshi M: Risk factors for intrahepatic recurrence in human small hepatocellular carcinoma. Gastroenterology 108: 768-775, 1995.

31. Shimozawa N and Hanazaki K: Longterm prognosis after hepatic resection for small hepatocellular carcinoma. J Am Coll Surg 198: 356-365, 2004.

32. Shah SA, Wei AC, Cleary WS, et al: Prognosis and results after resection of very large $(10 \mathrm{~cm})$ hepatocellular carcinoma. $\mathrm{J}$ Gastrointest Surg 11: 589-595, 2007.

33. Kamiyama T, Nakanishi K, Yokoo H, et al: Recurrence patterns after hepatectomy of hepatocellular carcinoma: implication of Milan criteria utilization. Ann Surg Oncol 16: 1560-1571, 2009. 